\title{
Pengaruh Organisasi Pembelajaran, Dukungan Sosial, dan Motivasi Kerja terhadap Kinerja Pegawai PT Bank Mandiri Cabang Bekasi
}

\author{
The Influence of Learning Organization, Social Support, and Work \\ Motivation on Employee Performance of PT Bank Mandiri Bekasi \\ Branch
}

Oleh:

\author{
Rochmad Fadjar Darmanto1); Anik Ariyanti'2) \\ "Sekolah Tinggi Ilmu Ekonomi IPWI Jakarta" 1,2) \\ rochmadfadjar@yahoo.co.id1); ariyanti.anik@yahoo.co.id²)
}

\begin{abstract}
ABSTRAK
Penelitian ini bertujuan mengetahui bahwa organisasi pembelajaran, dukungan sosial dan motivasi kerja berpengaruh terhadap kinerja pegawai PT Bank Mandiri Cabang Bekasi. Metode yang dipakai pada penelitian ini ialah metode pendekatan kuantitatif dan menggunakan analisis deskriptif serta verifikatif (regresi linier ganda). Jumlah sampel penelitian sebanyak 55 responden yang merupakan pegawai di PT Bank Mandiri (Persero) Tbk., Cabang Bekasi. Organisasi pembelajaran, dukungan sosial, dan motivasi kerja mempunyai pengaruh positif dan juga signifikan terhadap kinerja pegawai. Organisasi pembelajaran, dukungan sosial dan motivasi kerja secara parsial mempunyai pengaruh positif dan signifikan terhadap kinerja pegawai.
\end{abstract}

Kata kunci: organisasi pembelajaran; dukungan sosial; motivasi kerja; dan kinerja

\begin{abstract}
This research aims to find out that the organization of learning, social support and work motivation affects the performance of employees of PT Bank Mandiri Bekasi Branch. The method used in this study is a quantitative approach method and uses descriptive and verifiative analysis (double linear regression). The number of research samples as many as 55 respondents who are employees at PT Bank Mandiri (Persero) Tbk., Bekasi Branch. Organizational learning, social support, and work motivation have a positive and also significant influence on employee performance. The organization of learning, social support and work motivation partially has a positive and significant influence on employee performance.
\end{abstract}

Keywords: learning organization; social support; work motivation and performance. 


\section{PENDAHULUAN}

Globalisasi merupakan fenomena yang terjadi dalam peradaban manusia dan menuntut para pelaku usaha untuk meningkatkan keunggulan-keunggulan yang kompetitif agar tetap bisa bertahan. Dan persaingan global hanya dapat dimenangkan oleh perusahaan yang menguasai kekuatan-kekuatan untuk menang. Persaingan global memberikan tekanan-tekanan kepada perusahaanperusahaan agar mampu membenahi diri untuk meningkatkan kualitasnya, terutama kualitas sumber daya manusianya. Sumber daya manusia atau pegawai merupakan aset yang menjadi faktor sentral dan harus terus ditingkatkan kinerjanya. Konsep yang sangat tepat untuk meningkatkan kinerja pegawai adalah organisasi pembelajaran. Melalui organisasi pembelajaran, organisasi atau perusahaan akan mampu melakukan proses pembelajaran sehingga mempunyai kecepatan dalam berpikir maupun bertindak dalam merespon perubahanperubahan yang akan muncul (Senge, 2006).

Seperti dijelaskan oleh (Suryono, 2011) bahwa organisasi pembelajaran adalah sebuah institusi yang senantiasa belajar, secara kuat dan kolektif merubah diri dengan menggunakan pengetahuan yang lebih baik, memberdayakan orang dalam dan luar untuk belajar sekaligus bekerja demi kesuksesan organisasi.

Organisasi pembelajaran ialah organisasi terus belajar dan mempunyai kemampuan dalam memperbaiki kinerjanya secara terus-menerus. Upaya dalam membentuk organisasi pembelajaran (learning organization) perlu memperhatikan faktor budaya, strategi, struktur serta lingkungan pada organisasi (Tjakraatmadja, et al., 2014).

Parmono (dalam Haryanti, 2006) menjelaskan bahwa terdapat beberapa komponen agar dapat menjadi organisasi pembelajaran, yaitu adanya peluangpeluang, perancangan struktur serta budaya organisasi, adanya insentif, adanya prinsip penerimaan, adanya kesempatan serta hak yang sama, adanya keterbukaan, batas-batas yang ada semakin kabur, dan adanya pemahaman.

Pengembangan

organisasi pembelajaran atau learning organizaaton memiliki 6 (enam) fitur utama yaitu pembelajaran dan pengembangan yang berkelanjutan, generasi berpengetahuan dan berbagai pengetahuan, perubahan yang sistematis, budaya belajar, dorongan untuk fleksibel dan bereksperimen, dan menghargai pegawai. Penerapan organisasi pembelajaran dalam perusahaan perlu didukung dengan pembelajaran dengan tiga pendekatan yaitu terfragmentasi, terformulasi dan terfokus (Wirotama, 2017).

Lima dimensi dalam organisasi pembelajaran yang memungkinkan organisasi untuk terus belajar dan berkembang, adalah keahlian pribadi atau penguasaan diri (personal mastery) modelmodel mental (mental models), visi bersama (shared vision), dan pembelajaran tim (team learning), serta berpikir sistem (system thinking) (Senge, 2006).

Beberapa penelitian menjelaskan bahwa organisasi pembelajaran atau learning organization terbukti mempunyai pengaruh yang positif dan signifikan terhadap tingkat kinerja karyawan, seperti pendapat (Putri, 2020; Anggriawan \& Rusilawati, 2014). Organisasi pembelajaran menjelaskan proporsi yang cukup besar terhadap peningkatan kinerja karyawan (Anggara, et al., 2019).

Namun, ada penelitian lain (Uniati, 2014) yang menyatakan bahwa organisasi pembelajaran (learning organization) tidak ada efek langsung pada kinerja (organization performance) justru keterkaitan dan pengaruh organisasi pembelajaran pada beberapa aspek yaitu kepuasan kerja, komitmen kerja. Hal ini karena konsep organisasi pembelajaran yang ideal masih belum ditemukan). Ternyata hal yang sama juga ditemukan pada penelitian lain (Srimulatsih, 2021), yang menyebutkan bahwa organisasi pembelajaran tidak 
berdampak begitu banyak terhadap kinerja karyawan.

Ketidakkonsistenan pada hasil penelitian tersebut, semakin mendorong dilakukannya penelitian ini untuk meninjau lagi pengaruh organisasi pembelajaran atau learning organization terhadap tingkat kinerja karyawan. Dalam penelitian kali ini ditambahkan faktor lain yaitu dukungan sosial dan motivasi kerja dalam mempengaruhi kinerja. Dukungan sosial adalah bentuk penerimaan dari orang lain yang berwujud kenyamanan, kepedulian, penghargaan, atau bantuan lain yang mengakibatkan pegawai merasa disayangi, diperhatikan dihargai, dan ditolong. Ada empat aspek dalam dukungan sosial, aspek dukungan emosional, bentuk penghargaan, instrumental, informasi, serta dukungan kelompok (Sarafino, 2014).

Dukungan sosial adalah bentuk dukungan secara emosional yang mampu membuat seseorang merasa diperhatikan, dihargai dan dicintai serta bentuk bantuan yang melibatkan kondisi emosi, pemberian informasi, juga instrumen, serta penilaian yang positif kepada seorang individu (Apollo \& Cahyadi, 2012).

Sumber dukungan sosial meliputi dukungan sosial yang sifatnya artifisial dan dukungan sosial yang natural. Dukungan sosial artifisial merupakan dukungan yang dikhususkan untuk kebutuhan pokok seseorang. Dukungan sosial yang natural adalah dukungan natural diterima seseorang lewat transaksi sosial pada kehidupan mereka secara spontanitas (Kuntjoro, 2002).

Manfaat dukungan sosial ialah mampu untuk meminimalisir rasa cemas, depresi, serta simtom-simtom dalam gangguan pada orang yang mengalami kondisi stress di pekerjaan (Apollo \& Cahyadi, 2012:261). Pegawai sangat senang bila mendapatkan dukungan sosial dari perusahaan sehingga mereka semakin giat dalam bekerja. Pemilihan dukungan sosial sebagai faktor yang mampu mempengaruhi kinerja pegawai, didukung oleh penelitian-penelitian yang menjelaskan bahwa faktor dukungan sosial mempunyai berpengaruh signifikan terhadap kinerja pegawai, faktor dukungan sosial menjadi salah satu pendorong pegawai untuk berkinerja dengan baik (Adnyaswari \& Adnyani, 2017; Puspitasari, 2018), bahwa kinerja pegawai dapat dipengaruhi oleh dukungan sosial.

Dalam dukungan sosial terdapat hal penting yaitu dukungan emosional dan dukungan instrumental (Cyranowski, et al., 2014). Pendapat ini juga sejalan dengan pendapat Sonia (2021) bahwa peningkatan kinerja karyawan dipengaruhi oleh dukungan sosial yang meliputi dukungan emosional, bentuk penghargaan, bentuk instrumental maupun dukungan bentuk informasi.

Peningkatan kinerja pegawai juga dipengaruhi motivasi kerja yang merupakan kekuatan seseorang untuk menimbulkan semangat dan antusiasme dalam menjalankan suatu pekerjaan. Aspek-aspek dalam motivasi kerja meliputi: kedisiplinan yang dimiliki oleh pegawai, tingginya imajinasi pegawai serta daya kombinasi, percaya diri, daya tahan pada setiap tekanan, serta dikuatkan dengan tanggung jawab (Munandar, 2012). Aspek lain dari motivasi kerja adalah perilaku atau direction of behavior, tingkat usaha atau level of effort, serta tingkat kegigihan atau level of persistence (George \& Jones, 2012). Faktor-faktor yang mendukung motivasi kerja meliputi pengawasan atau supervise, hubungan antar pribadi atau interpersonal relation, gaji, pemenuhan kebutuhan dan keinginan karyawan, kepuasan kerja, serta prestasi kerja karyawan (Wirawan, 2013).

Pemilihan motivasi sebagai faktor yang mempengaruhi kinerja pegawai didasari oleh hasil dari penelitian yang menyimpulkan bahwa motivasi kerja karyawan berpengaruh yang signifikan dan juga positif terhadap kinerjanya seperti pendapat (Sanjaya, 2018; Cahyaningtias, 2018; Susita \& Setyawati, 2020; Noer, et al., 2020). 
Kinerja atau diartikan juga dengan hasil-hasil yang diperoleh dari kegiatan yang dilakukan individu dalam kelompok orgnisasi yang juga dipengaruhi oleh faktor-faktor guna mencapai tujuan dari organisasi pada jangka waktu tertentu (Tika, 2014). Aspek-aspek dari kinerja adalah hasil kerja, kedisiplinan, tanggung jawab, dan kemampuan kerjasama (Mangkunegara, 2017).

Instrumen yang dipakai untuk mengukur kinerja yaitu kuantitas dan kualitas kerja, pengetahuan tentang pekerjaan, serta perencanaan kegiatan. Kinerja pegawai merupakan tingkat pencapaian kerja dan pelaksanaan kerja untuk mewujudkan visi, misi, tujuan serta sasaran dari organisasi yang ada dalam perencanaan dan juga strategi organisasi. Kinerja, asalnya katanya job performance atau disebut juga actual performance artinya adalah bentuk prestasi kerja yang dicapai oleh pegawai (Moeheriono, 2012).

Penelitian ini mengambil objek pada PT Bank Mandiri (Persero) Tbk, Cabang Bekasi. PT Bank Mandiri (Persero) Tbk Cabang Bekasi, memiliki tata kelola perusahaan yang baik dibuktikan dalam The Best GRC Overall for Corporate Governance and Performance yang digelar Majalah Business News Indonesia kerjasama dengan CEO Forum. Selain itu, juga meraih sebuah predikat "Sangat Terpercaya" 14 (empat belas) kali secara berturut-turut. Selain itu PT Bank Mandiri masuk dalam ASEAN Asset Class yaitu pemeringkatan pada ASEAN Corporate Governance Scorecard (ACGS) oleh ASEAN Market Forum.

Sejak awal berdiri, Bank Mandiri (Persero) telah mengutamakan pentingnya penerapan program pengembangan SDM secara kreatif untuk menciptakan talenta mampu beradaptasi dengan berbagai perubahan. PT Bank Mandiri (Persero) Tbk. Cabang Bekasi mulai berdiri pada 2 Oktober 1998 merupakan bagian dari program restrukturisasi perbankan yang dilakukan pemerintah Indonesia. Implemantasi budaya yang dilakukan Bank Mandiri adalah restrukturisasi berbasis pada kinerja, penataan ulang pada sistem berbasis kinerja, pengembangan pada leadership, talent, serta penyesuaian pegawai/sumber daya manusia pada kebutuhan strategis.

PT Bank Mandiri menjadi bank terbaik di Indonesia dengan slogan "Terdepan, Terpercaya, dan Tumbuh Bersama Anda". PT Bank Mandiri telah melakukan transformasi budaya yang mengarahkan nilai-nilai dalam budaya yang digunakan pegawai sebagai pedoman dalam berperilaku yang disingkat TIPCE (Trust, Integrity, Professionalism, Customer Focus, $\mathcal{E}$ Excellence).

Penelitian ini mengangkat organisasi pembelajaran, dukungan sosial serta motivasi kerja sebagai faktor yang mampu mempengaruhi kinerja pegawai, alasan utama mengangkat masalah tersebut adalah karena masih relatif sedikit penelitian yang membahas masalah tersebut, sehingga dianggap masih perlu penelitian lanjutan.

\section{METODE PENELITIAN}

\section{Populasi danSampel}

Populasi pada penelitian kali ini ialah pegawai di PT Bank Mandiri (Persero), Tbk. Cabang Bekasi, sebanyak 55 orang. Menurut Sugiyono (2019) sampel ialah bagian dari jumlah dan karakteristik yang dimiliki populasi. Arikunto (2016) menjelaskan bahwa sampel adalah bagian dari populasi yang akan diteliti. Jika subjek kurang dari 100, maka lebih baik jumlah tersebut diambil semuanya dan jika subjek lebih dari 100, maka yang diambil 10\%$15 \%$-nya.

Jumlah populasi pada penelitian ini ternyata kurang dari 100 maka teknik sampling menggunakan sampel jenuh. Sampel jenuh ialah teknik untuk menentukan sampel dengan langkah mengambil semua populasi sebagai responden atau sampel sehingga sampel pada penelitian ini berjumlah 55 orang responden. 


\section{Desain Penelitian}

Desain penelitian di gambar 1 terdapat empat variabel pada penelitian ini terdiri atas 3 (tiga) variabel independen yaitu variabel $\mathrm{X} 1$ : organisasi pembelajaran, variabel X2: dukungan dosial, variabel X3: motivasi kerja dan 1 (satu) variabel dependen yaitu variabel $Y$ : kinerja. Gambar 1 tersebut menunjukkan ada pengaruh antar variabel yaitu organisasi pembelajaran (X1), dukungan Sosial (X2), motivasi kerja (X3) dan kinerja (Y). Peningkatan kinerja pegawai dipengaruhi oleh penerapan organisasi pembelajaran dalam organisasi, didukung oleh pemberian dukungan sosial kepada pegawai yang tepat dan tingkat motivasi kerja pegawai yang terus meningkat.

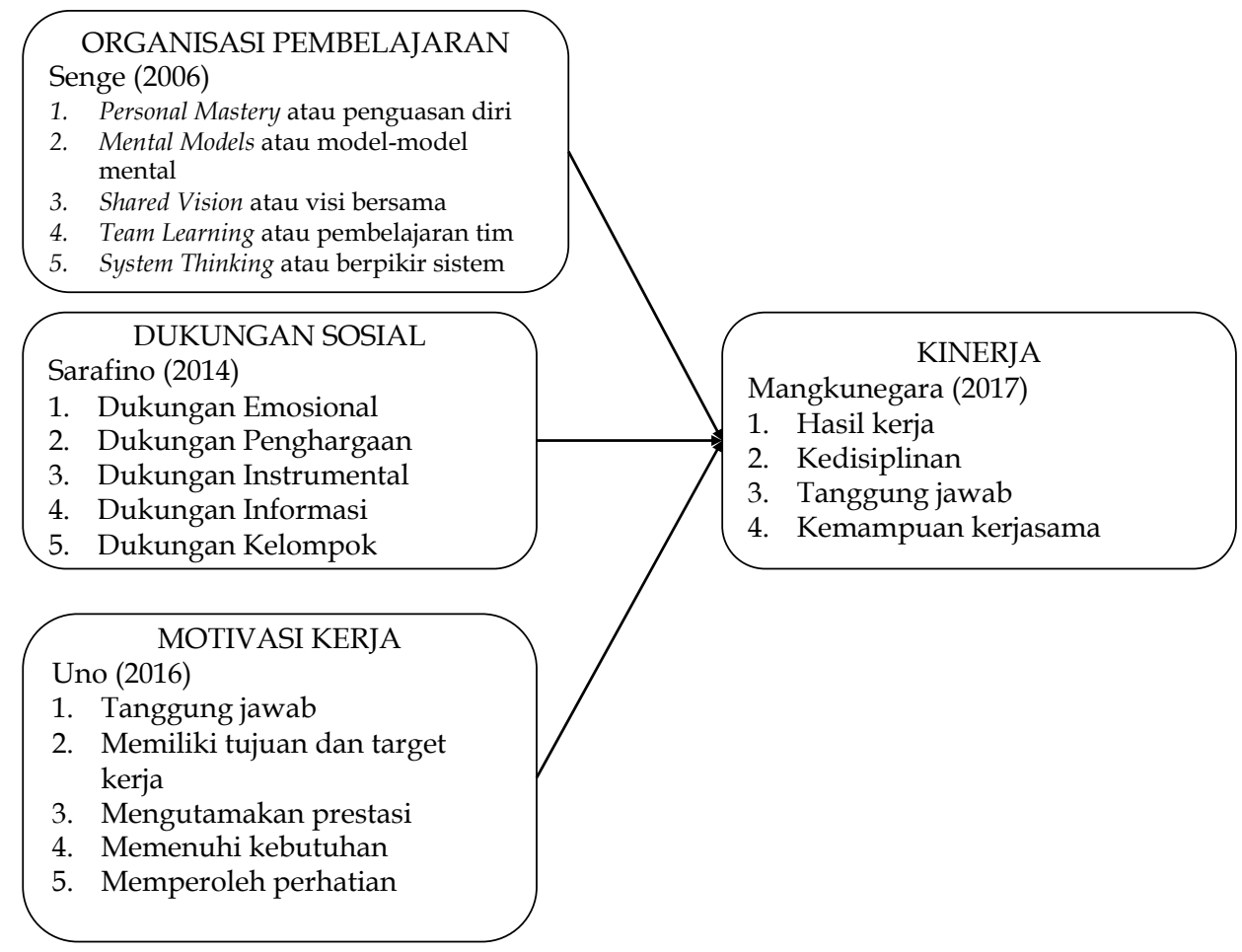

Sumber: data diolah, 2021

Gambar 1. Desain Penelitian

\section{Uji Instrumen}

Uji instrumen pada penelitian ini dilakukan dengan uji validitas dan uji reliabilitas guna melihat apakah kuesioner yang dibuat bisa dipahami oleh responden serta mempunyai konsistensi dalam pengukuran (Ghozali, 2018).

Uji validitas menggunakan cara membandingkan nilai $r$ hitung $>r$ tabel, artinya kuesioner penelitian dinyatakan valid. Pernyataan valid apabila nilai korelasi yang ada di dalam kolom pada Corrected Item Correlation $>0,300$. Uji reliabilitas merupakan indeks yang menandakan sejauh mana alat pengukur bisa dipercaya dan bisa diandalkan (Ghozali, 2018). Pengambilan keputusan pada uji reliabilitas didasari dari nilai Cronbach's Alpha $>0,60$ (Nunnally dalam Mulyanto \& Wulandari, 2010).

\section{Metode Analisis Data}

Metode dalam penelitian ini yaitu metode pendekatan kuantitatif dengan menggunakan analisis deskriptif verifikatif dengan regresi linier ganda. Analisis deskriptif ini bertujuan mendeskripsikan data pada penelitian, dan analisis linier ganda sebagai menguji atas pengaruh beberapa variabel independen terhadap 1 
(satu) variabel dependen. Analisis penelitian ini menggunakan software SPSS versi 16. Sebelum analisis regresi ganda, perlu melakukan uji prasyarat analisis dengan uji asumsi klasik bertujuan untuk membuktikan metode persamaan regresi linier ganda bisa diterima karena memenuhi pernaksiran BLUE (Best Linier Unibiased Estimator) yang berarti penaksiran tidak bias, linier serta konsisten.

Uji asumsi meliputi uji normalitas, uji multikolinieritas, serta uji heteroskedastisitas. Uji Normalitas, menjelaskan jika data dari variabel penelitian adalah dari data variabel yang mempunyai distribusi normal. Penelitian ini memakai grafik P-P Plot yang terpenuhi apabila titik-titik yang ada di grafik $P-P$ Plot menyebar pada sekitar garis dan/atau mengikuti arah garis diagonal grafik.

Uji Multikolinieritas, menjelaskan jika ada korelasi sangat kuat antar variabel bebas. Dan hal ini tidak diharapkan artinya pengujian perlu dilakukan lagi untuk memastikan tidak ada multikolinieritas. Pengujiannya dilakukan dengan cara melihat nilai toleransi/telerance dan nilai $V I F$, yaitu nilai dari VIF tidak lebih besar 10 dan nilai Tolerance $>0,2$.

Uji Heteroskedastisitas, dimana pengujian ini untuk memastikan bahwa tidak terjadi masalah heteroskedastisitas model persamaan regresi ganda. Pengujian pada grafik scatter plot, apabila titik-titik di grafik tersebar acak dan tidak menunjukkan pola tertentu, maka uji asumsi bisa terpenuhi.

Setelah semua uji asumsi dapat terpenuhi, selanjutnya melakukan analisis regresi linier ganda dengan $\mathrm{Y}=\mathrm{a}+\mathrm{b} 1 \mathrm{X} 2+\mathrm{b} 2 \mathrm{X} 2+\mathrm{b} 3 \mathrm{X3}$, artinya nilai $\mathrm{a}$ adalah konstan, nilai $\mathrm{Y}=$ Kinerja, $\mathrm{X} 1=$ Organisasi pembelajaran, $\mathrm{X} 2=$ Dukungan Sosial, dan X3 = Motivasi Kerja.

\section{Uji Hipotesis}

Sebelum dilakukan pengujian hipotesis, maka terlebih dahulu dilakukan uji kelayakan model terlebih dahulu. Uji kelayakan model atau goodness of fit ini bertujuan untuk menguji ketepatan fungsi regresi sampel dalam menaksirkan nilai aktual secara statistik. Model goodness of fit bisa diukur dari nilai $\mathrm{F}$ dengan kriteria apabila $p$-value $<0,05$, maka uji model layak untuk penelitian dan apabila nilai $p$ value $>0,05$, maka uji model tidak layak untuk penelitian (Ghozali, 2018).

Jika model penelitian telah memenuhi kategori kelayakan model, maka pengujian atas hipotesis dilanjutkan menggunakan uji-t, dengan membandingkan probabilitas atau sig terhadap taraf uji $(0,05)$.

\section{HASIL PENELITIAN}

\section{Responden Penelitian}

Responden pada penelitian ini yaitu pegawai tetap di PT Bank Mandiri (Persero) Tbk, Cabang Bekasi, dengan karakteristik berdasarkan tingkat pendidikan S1 sebanyak 49,1\%, S2 sebanyak $18,2 \%$, D3 sebanyak $12,7 \%$, SLTA sebanyak $20 \%$. Hal membuktikan bahwa responden didominasi lulusan sarjana. Kondisi ini memberikan gambaran bahwa perusahaan lebih mengutamakan lulusan Sarjana. Usia responden yaitu 38,2\% usia antara 31-40 tahun, 25,5\% usia antara 25-30 tahun, $21,8 \%$ usia $<40$ tahun. Kondisi ini juga memberikan gambaran bahwa usia pegawai rata-rata produktif dan masih mempunyai waktu yang lama untuk berkarya. Masa kerja 58,2\% $<5$ tahun dan $41,8 \%>5$ tahun. Artinya responden sudah berkarya cukup lama dan tentunya mempunyai pengalaman kerja yang baik.

\section{Uji Validitas dan Reliabilitas}

Uji validitas, menghasilkan nilai $r$ hitung $>r$ tabel dan semua kuesioner masing-masing variabel independen yaitu: organisasi pembelajaran, dukungan sosial, motivasi kerja dan kinerja dinyatakan valid, dengan bukti nilai corrected item-total correlation $>0,30$. Pada uji reliabilitas dibuktikan nilai Cronbach's Alpha untuk tiap-tiap variabel tersebut mempunyai nilai $>0,60$, artinya semua item berkategori reliabel atau handal (Sugiyono, 2019). 


\section{Analisis Deskriptif}

Analisis deskripsi pada variabel penelitian, menunjukkan hasil temuan relatif sama pada semua variabel. Persepsi responden atas organisasi pembelajaran pada indikator personal mastery artinya penguasaan diri, mental models artinya model-model mental, shared vision artinya visi bersama, team learning artinya pembelajaran tim serta system thinking artinya berpikir sistem, cenderung cukup baik dengan nilai rata-rata 36,20. Persepsi responden atas dukungan sosial pada indikator dukungan emosional, penghargaan, instrumental, infomasi, dan kelompok cenderung cukup baik dengan nilai rata-rata 36,24. Persepsi responden atas motivasi kerja pada indikator tanggung jawab, memiliki tujuan dan target kerja, mengutamakan prestasi, memenuhi kebutuhah, dan memperoleh perhatian, cenderung cukup baik dengan nilai rata-rata 37,36. Persepsi responden atas kinerja pada indikator hasil kerja, kedisiplinan, tanggung jawab dan kemampuan kerjasama cenderung cukup baik dengan nilai rata-rata 37,30.

\section{Analisis Data}

Sebelum melakukan uji regresi linier ganda, terlebih dahulu melakukan uji prasyarat analisis yaitu menguji normalitas, multikolinieritas, dan uji heteroskedastisitas. Uji normalitas data dengan grafik menunjukkan grafik normal P-P Plot yang ditandai titik-titik nilai residual di grafik menyebar di sekitaran garis dan mengikuti arah pada garis diagonal. Artinya, data variabel berasal dari data dengan distribusi normal. Hasil pengujian menunjukkan bahwa nilai Tolerance $>0,1$ serta nilai Variance Inflation Factor (VIF) menunjukkan bahwa masingmasing variabel bebas tidak ada yang memiliki nilai Tolerance $>0,1$ serta nilai VIF lebih rendah dari persyaratan yang minimal yaitu $<10$. Artinya, analisis regresi linier ganda tidak terjadi multikolinieritas.

Pada uji heteroskedastisitas ditunjukan dari grafik terlihat bawha titiktitik menyebar acak dan tidak membentuk suatu pola, maka uji asumsi ini terpenuhi karena tidak bermasalah heteroskedastisitas dan analisis regresi linier ganda bisa dilanjutkan. Persyaratan untuk analisis dengan asumsi klasik dapat terpenuhi yang terbukti pada normalitas, tidak terjadi multikolinieritas serta tidak juga terjadi heteroskedastisitas, sehingga analisis regresi linier ganda bisa dilanjutkan.

\section{Uji Model}

Langkah pertama yang dilakukan sebelum dilakukan uji hipotesis adalah melakukan uji model, dengan tujuan untuk mengetahui layak tidaknya model persamaan regresi linier ganda yaitu dengan cara melihat nilai pada Adjusted $R$ Square dan melakukan Uji $F$ adalah dengan membandingkan nilai probabilitas (sig $F$ ), seperti pada tabel berikut:

Tabel 1. Model Summary

\begin{tabular}{cccc}
\hline $\mathrm{R}$ & $\mathrm{R}$ Square & Adjusted R Square & Std. Error of the Estimate \\
\hline 0.872 & 0.761 & 0.746 & 2.458 \\
\hline
\end{tabular}

Sumber: SPSS, 2021

Kelayakan model dapat dilihat dari nilai koefisien determinasi ganda yang disesuaikan dengan Adjusted $R$ Square yaitu sebesar 0,746 atau $74,6 \%$ nilai kinerja dipengaruhi oleh organisasi pembelajaran, dukungan sosial, dan motivasi kerja. dan mempunyai nilai probabilitas (Sig) $F$ hitung sebesar $0,000<0,05$, arinya model persamaan regresi dari hasil penelitian layak dalam menjelaskan pengaruh 
organisasi pembelajaran, dukungan sosial dan motivasi kerja terhadap kinerja. Uji model dibuktikan hail analisis berupa tabel anova (tabel 2).

\section{Tabel 2. Uji F}

ANOVA ${ }^{b}$

\begin{tabular}{rlccccc}
\hline & Model & Sum of Squares & df & Mean Square & F & Sig. \\
\hline & Regression & 978.85 & 3 & 326.283 & 54.004 & $.000^{\mathrm{a}}$ \\
\multirow{2}{*}{1} & Residual & 308.132 & 51 & 6.042 & & \\
\cline { 3 - 6 } & Total & 1286.982 & 54 & & & \\
\hline
\end{tabular}

a. Predictors: (Constant), Motivasi Kerja, Organisasi pembelajaran, Dukungan Sosial

b. Dependent Variable: Kinerja

Sumber: SPSS, 2021

Tabel 3. Hasil Analisis Regresi

\begin{tabular}{lcccccc}
\hline \multirow{2}{*}{ Model } & \multicolumn{2}{c}{$\begin{array}{c}\text { Unstandard } \\
\text { ized Coefficients }\end{array}$} & $\begin{array}{c}\text { Standardized } \\
\text { Coefficients }\end{array}$ & \multirow{2}{*}{$\mathrm{t}$} & Sig \\
\cline { 2 - 5 } & $\mathrm{B}$ & Std Eror & Beta & & \\
\hline Constant & 2.651 & 2.928 & & 0.905 & 0.369 \\
Organisasi Pembelajaran & 0.336 & 0.117 & 0.373 & 2.875 & 0.006 \\
Duk Sos & 0.353 & 0.144 & 0.346 & 2.455 & 0.018 \\
Motivasi Kerja & 0.263 & 0.1 & 0.244 & 2.619 & 0.012 \\
\hline
\end{tabular}

Dependent Variabel: Kinerja

Sumber: SPSS, 2021

\section{Uji Hipotesis}

Tabel 3 menghasilkan nilai persamaan regresi linier ganda $Y=2,651+0,336 \times 1+$ $0,353 X 2+0,263 X 3$. Konstanta sebesar $\mathrm{a}=2,651$, menunjukkan bahwa $\mathrm{Y}$ (Kinerja) bernilai positif dengan asumsi variabel $\mathrm{X} 1$, $\mathrm{X} 2$, dan X3 dianggap konstan. Variabel organisasi pembelajaran mempunyai nilai $t$ hitung 2,875 dengan nilai probabilitas (Sig) sebesar 0,006 < 0,05 serta koefisien variabel sebesar 0,336 yang artinya mengarah positif, dimana jika organisasi pembelajaran meningkat maka nilai kinerja meningkat. Dapat ditarik kesimpulan bahwa hipotesis 1 (H1) dapat diterima.

Variabel dukungan sosial (X2) mempunyai nilai $\mathrm{t}$ hitung 2,455 dengan nilai probabilitas (Sig) sebesar 0,018 $<0,05$, pada koefisien variabel sebesar 0,353 yang artinya mengarah positif, dimana jika dukungan sosial meningkat maka nilai kinerja meningkat. Dapat disimpulkan bahwa hipotesis $2(\mathrm{H} 2)$ dapat diterima.

Variabel motivasi kerja (X3) mempunyai nilai $t$ hitung 2,619 dengan nilai probabilitas (Sig) sebesar 0,012 < 0,05 dan koefisien variabel sebesar 0,263 yang artinya mengarah positif, dimana apabila motivasi kerja ditingkatkan maka nilai kinerja meningkat. Disimpulkan bahwa hipotesis $3(\mathrm{H} 3)$ dapat diterima.

\section{PEMBAHASAN}

\section{Pengaruh Organisasi Pembelajaran terhadap Kinerja Pegawai}

Hasil uji kelayakan model persamaan regresi membuktikan bahwa organisasi pembelajaran terbukti mempunyai pengaruh signifikan positif terhadap kinerja pegawai dengan nilai 
0,336. Nilai pengaruh ini menunjukkan bahwa organisasi pembelajaran yang efektif akan memungkinkan PT Bank Mandiri (Persero), Tbk., Cabang Bekasi mampu memperluas kapasitas pegawai sebagai personal mastery artinya penguasaan diri, mental models artinya model-model mental, shared vision artinya visi bersama, team learning artinya pembelajaran tim serta system thinking artinya berpikir sistem sehingga akan berpengaruh terhadap kinerja pegawainya.

Pegawai yang mempunyai personal mastery yang unggul tidak hanya akan membawa kemajuan tetapi juga kesuksesan untuk perusahaan maupun dirinya. Mental models pada pegawai akan membuat pegawai mampu berpikir serta menggunakan ide dalam berinteraksi. Pegawai yang mempunyai Shared vision akan mempunyai kekuatan untuk mencapai tujuan.

Menurut Senge (2006) shared vision merupakan satu dari empat inti disiplin yang diperlukan untuk membangun organisasi. Peranan team learning akan membentuk pegawai mampu menciptakan identitas bersama, menyelaraskan dan membangun kapasitas tim untuk mencapai tujuan bersama. Dengan system thinking diharapkan pegawai Bank Mandiri (Persero), Tbk., Cabang Bekasi mampu memandang sesuatu hal secara keseluruhan dan memahami setiap bagian saling berhubungan. Hal tersebut sesuai dengan pendapat (Hurliman, et al., 2009) bahwa System thinking lebih menekankan pada suatu kesadaran tentang segala sesuatu yang berkaitan dalam satu rangkaian sistem.

Jika PT Bank Mandiri mampu meningkatkan organisasi pembelajaran khususnya pada faktor personal mastery atau penguasaan diri, mental models atau model-model mental, shared vision atau visi bersama, team learning atau pembelajaran tim serta system thinking atau berpikir sistem, maka kinerja pegawai akan semakin meningkat lebih baik. Dengan kata lain kinerja organisasi akan meningkat dikarenakan adanya peningkatan pada kompetensi pegawai karena telah melakukan pembelajaran secara terusmenerus atau berkelanjutan dengan menerapkan organisasi pembelajaran. Pendapat ini mendukung pendapat (Ressya, 2014; Matturungan, et al., 2016; Basori, 2017; Herawati \& Purwanto, 2017; Pratiwi, et al., 2019; Harimu, et al., 2021) bahwa organisasi pembelajaran mempunyai pengaruh positif dan juga signifikan terhadap kinerja pegawai. Faktor-faktor organisasi pembelajaran yang meliputi visi, strategi serta karakteristik karyawan mempunyai pengaruh terhadap peningkatan kinerja. Dan untuk menjadi organisasi pembelajaran konsep utamanya adalah organisasi harus mampu secara terusmenerus melakukan self learning agar mempunyai kekuatan berpikir juga bertindak saat menghadapi berbagai macam kondisi yang akan muncul (Senge, 2006).

\section{Pengaruh Dukungan Sosial terhadap Kinerja Pegawai}

Dukungan sosial berpengaruh signifikan dan juga positif terhadap peningkatan kinerja pegawai sebesar 0,353. Bentuk dukungan sosial seperti dukungan emosional dalam pemberian perhatian, kepercayaan, empati dan kepedulian kepada pegawai bisa membuat pegawai merasa diperhatikan, dipercaya dan dipedulikan. Dukungan penghargaan juga perlu diberikan kepada pegawai sebagai bentuk imbal jasa atas kinerja yang telah dihasilkan. Selain itu, dukungan instrumental yang berupa fasilitas dan materi yang dibutuhkan untuk membantu meringankan tugas. Dukungan informasi yang berupa petunjuk-petunjuk, nasehat, usulan atau saran-saran dan juga umpan balik, juga sangat dibutuhkan para pegawai untuk menambah wawasan, pengetahuan dan pemahaman terhadap tugas yang diembannya. Dan yang tidak kalah penting lagi adalah dukungan kelompok yang memungkinkan pegawai merasa menjadi bagian dari yang lain dan 
dapat melakukan kolaborasi dan kerjasama dengan itikat baik untuk mencapai tujuan yang ditetapkan.

Jika semua bentuk dukungan sosial baik dalam bentuk dukungan emosional, penghargaan, instrumental, informasi, serta dukungan kelompok ditingkatkan, maka akan berpengaruh pada peningkatan kinerja pegawai. Hal ini mendukung pendapat (Muhaimin, et al., 2013; Adnyaswari \& Adnyani, 2017; Sitepu, 2018; Sonia, 2021) bahwa dukungan sosial berpengaruh signifikan dan positif terhadap tingkat kinerja, sehingga dapat diartikan bahwa semakin tinggi dukungan sosial diberikan maka semakin tinggi kinerja pegawai. Semua bentuk dukungan sosial tersebut mampu memberikan kenyamanan fisik serta psikologis pada pegawai sehingga berpengaruh pada tingkat kinerjanya. Semakin bagus dukungan sosial akan lebih meningkatkan kinerja pegawai. Dukungan sosial juga mampu memberikan semangat kepada individu untuk menjalankan aktivitas dengan baik. Seorang pegawai yang memperoleh dukungan sosial tinggi, tentunya akan menunjukkan kinerja yang lebih baik daripada pegawai yang kurang mendapat dukungan sosial (Sarafino, 2014). Penelitian ini, membuktikan bahwa pengaruh dukungan sosial terhadap kinerja lebih besar dibandingkan organisasi pembelajaran dan motivasi kerja.

\section{Pengaruh Motivasi Kerja terhadap Kinerja Pegawai}

Motivasi kerja mempunyai pengaruh signifikan dan juga positif terhadap tingkat kinerja pegawai sebesar 0,263. Adanya sikap yang penuh tanggung jawab, memiliki tujuan dan target kerja yang jelas, lebih mengutamakan prestasi, mengharapkan kebutuhan terpenuhi, dan perhatian terbukti berdampak pada peningkatan kinerja pegawai. Motivasi kerja menjadi faktor penting dalam mendukung PT Bank Mandiri (Persero), Tbk, Cabang Bekasi untuk mencapai tujuannya. Hasil penelitian ini mendukung pendapat (Cahyaningtias, 2018; Sanjaya, 2018; Susita \& Setyawati, 2020; Noer, et al., 2020) motivasi kerja mempunyai pengaruh positif terhadap kinerja pegawai. Motivasi kerja merupakan proses yang bisa membangkitkan pada perilaku pegawai, mempertahankan kemajuan perilaku pegawai, serta menyalurkan perilaku dan tindakan yang sangat spesifik (Chukwuma \& Obiefuna, 2014). Motivasi kerja adalah bentuk kekuatan yang ada pada diri seseorang yang bisa mempengaruhi arah, intensitas serta ketekunan perilaku sukarela dalam melakukan pekerjaan. Semakin tinggi intesitas, ketekunan serta perilaku sukarela ini sangat berpengaruh pada tingkat kinerja pegawai (Uno, 2016).

\section{KESIMPULAN}

Organisasi pembelajaran berpengaruh signifikan dan positif terhadap kinerja pegawai PT Bank Mandiri (Persero) Tbk, Cabang Bekasi. Dukungan sosial berpengaruh signifikan dan positif terhadap kinerja pegawai PT Bank Mandiri (Persero) Tbk., Cabang Bekasi, dan motivasi kerja berpengaruh signifikan dan positif terhadap kinerja pegawai PT Bank Mandiri (Persero) Tbk., Cabang Bekasi.

Peningkatan organisasi pembelajaran pada PT Bank Mandiri (Persero) Cabang Bekasi akan membekali organisasi dalam basis pengetahuan sehingga mampu membantu memenangkan persaingan sehingga, siap untuk berkompetisi, dan berkolaborasi. Dukungan sosial terhadap pegawai menjadi faktor yang dapat meningkatkan kinerja pegawai di PT Bank Mandiri (Persero) Tbk., Cabang Bekasi. Karena dengan mendapatkan dukungan sosial, pegawai akan merasa dihargai, diperhatikan dan diakui. Faktor motivasi kerja sangat penting dan sangat besar pengaruhnya terhadap kinerja pegawai di PT Bank Mandiri (Persero) Tbk., Cabang Bekasi sehingga perusahaan harus tetap berkomitmen untuk terus meningkatkan motivasi kerja pegawai.

Penelitian ini masih perlu penyempurnaan, karena masih banyak 
keterbatasan sehingga diperlukan penelitian lanjutan yang melibatkan perbankan lainnya, dengan sampel yang lebih luas serta perlu ditambahkan dimensi lain yang makin kuat mempengaruhi peningkatan kinerja.

\section{DAFTAR PUSTAKA}

Adnyaswari, N.A., \& Adnyani, I.G. (2017). Pengaruh Dukungan Sosial dan Burnout terhadap Kinerja Perawat Rawat Inap RSUP Sanglah. E-Jurnal Manajemen Unud, 6(ISSN 23028912), h. 24742500 .

doi https://ojs.unud.ac.id/index.php/Manajemen/article/view/28874.

Anggara, W. G., Febriansyah, H., Darmawan, R., \& Cintyawati, C. (2019). Learning Organization and work performance in Bandung city government in Indonesia: a path modeling statistical approach. Development and Learning in Organizations, Vol.33(No.5), 12-15. https:/ / doi.org/10.1108/DLO-03-2018-0033

Anggriawan, E., \& Rusilawai, U. (2014). Pengaruh Organisasi Pembelajaran (Learning Organization) terhadap Kinerja Pegawai (Pada PT Bank Central Asia, Tbk. Area Kantor Cabang Utama (Taman Dutamas). Jurnal Ilmiah Prodi Manajemen Universitas Pamulang, Vol 2 (No.1). Doi: http://dx.doi.org/10.32493/jk.v2i1.y2014.p\%25p.

Apollo \& Cahyadi, A. (2012). Konflik Peran Ganda Perempuan Menikah yang Bekerja ditinjau dari Dukungan Sosial Keluarga \& Penyesuaian Diri. Widya Warta, No.2,h.254-271. http://repository.widyamandala.ac.id/446/1/6.\%20pak\%20apollo\%20254-271.pdf.

Arikunto, S. (2016). Prosedur Penelitian suatu Pendekatan Praktik. Jakarta: PT RinekaCipta.

Basori, M. (2017). Pengaruh Learning Organization terhadap Kinerja Organisasi dengan Organisasi sebagai Variabel Moderasi pada Perpustakaan Univ. Airlangga. Repository. http://repository.unair.ac.id/id/eprint/68373.

Cahyaningtias, D. P. (2018). Pengaruh Motivasi Kerja terhadap Kinerja Pegawai PT Neyva Putri Sriwijaya. Repository. https://repository.unsri.ac.id

Chukwuma, Maduka, E., \& Okafor, O. (2014). Effect of Motivation on Employee Productivity: A Study of Manufactoring Companies in Nnewi. International Jurnal of Managerial Studies and Research, 2 (7)137-147 https:// www.arcjournals.org/pdfs/ijmsr/v2-i7/14.pdf

Cyranowski, Zill, et al. (2014). Assessing Social Support, Companionship, and Distress: NIH Toolbox Adult Social Relationship Scales. Health Psychol, 32 (3) 293-301 https:// pubmed.ncbi.nlm.nih.gov/23437856/

Ghozali, I. (2018). Aplikasi Analisis Multivariate dengan Program IBM SPSS 25. Semarang: Badan Penerbit Undip.

George, J., \& Jones, G.R. (2012). Understanding and Managing Organization Behavior. Jew-Jersey: Pearson Education Inc.

Harimu, Y.E., et al. (2021). Pengaruh Knowledge Management dan Learning Organization terhadap Kinerja Karyawan PT Hasjrat Abadi Manado. Jurnal Productivity, 2(1), 47-51. https://ejournal.unsrat.ac.id/index.php/productivity/article/view/32586/0

Haryanti, A.S. (2006). Analisis Faktor-Faktor yang Menjadi Prediktor Organisasi Pembelajaran untuk Meningkatkan Kinerja Karyawan (Study Kasus pada PT Gramedia Pustaka Utama Jakarta. Retrieved from https://core.ac.uk/reader/11716130

Herawati, T \& Purwanto. (2017). Organisasi Pembelajaran, Kompetensi dan Kinerja Karyawan. Jurnal Muara Ilmu Ekonomi dan Bisnis,1(2),h.136-151. https://journal.untar.ac.id

Hurliman, A., Dolnicar, S., \& Mayer, P. (2009). Understanding behaviour to inform water supply management in developed nations - A review of literature, conceptual model 
and research agenda. Journal of Environmental Management, 91 (1), 47-56. Doi: http://dx.doi.org/10.1016/j.jenvman.2009.07.014

Kuntjoro. (2002). Manajemen Sumber Daya Manusia. Jakarta: PT Rajawali.

Mangkunegara, A.A. (2017). Manajemen Sumber Daya Manusia. Bandung: Roda.

Matturungan, N. H., Kurniawan, R., \& Sukmawati, A. (2016). Pengaruh Learning Organization, Kualitas Pendidikan, dan Pengalaman Kerja terhadap Peningkatan Kinerja Pegawai di BBSDLP Bogor Khususnya di Bidang Pelayanan Publik. Jurnal $\begin{array}{lllll}\text { Aplikasi Manajemen } & \text { (JAM), } & \text { Vol } & \text { 14(No.2). }\end{array}$ http://dx.doi.org/10.18202/jam23026332.14.2.08

Moeheriono. (2012). Pengaruh Kinerja Berbasis Kompetensi. Jakarta: Raja Grafindo Persada.

Muhaimin, B., Purnomo, E., \& Sutrisno. (2013). Pengaruh Dukungan Sosial dan Insentif terhadap Kinerja Pegawai KUA Tri Jaya Sraten Banyuwangi. Artikel Ilmiah Hasil Penelitian Mahasiswa. Univ Jember, Jember. http://repository.unej.ac.id/bitstream/handle/123456789/59109/Bibit\%20Muhaimin. pdf?sequence $=1$ \&isAllowed $=y$

Mulyanto, H., \& Wulandari, A. (2010). Penelitian: Metode $\mathcal{E}$ Analisis. Semarang: CV. Agung. Munandar, A.S., (2012). Psikologi Industri \& Organisasi. Jakarta: Univ. Indonesia

Noer, R. N., Rachmawati, I., \& Basori, Y. F. (2020). Pengaruh Motivasi Kerja terhadap Kinerja Pegawai Billing Manajemen di PT Haleyora Power ULP Sukabumi Kota. Binamika Jurnal Ilmiah Ilmu Administrasi Negara, Vol 7(No.2), h.323-332. http://dx.doi.org/10.25157/dinamika.v7i2.3653

Pratiwi, U., Ulfah, P., \& Lestari, P. (2019). Pengaruh Organisasi Pembelajaran terhadap Kinerja UMKM di Banyumas. Prosiding Seminar Nasional dan Call for Papers. Vol 9, pp. 58-67. Purwokerto:

LP3M Unisoed.http://jurnal.lppm.unsoed.ac.id/ojs/index.php/Prosiding/article/viewFile/ $1198 / 1049$

Puspitasari, K. D. (2018). Pengaruh Beban Kerja dan Dukungan Sosial terhadap Kinerja Pegawai pada PT Perkebunan Nusantara X Pabrik Gula Lestari di Nganjuk. Jurnal Ilmu Manajemen (JIM), Vol.4 (No.4) 394-400 E-ISSN:2549-192X. https://jurnalmahasiswa.unesa.ac.id/index.php/jim/article/view/24379/22306.

Putri, S.A. (2020). Pengaruh Learning Organization terhadap Kinerja Karyawan melalui Work Engagement pada Karyawan Bank Bukopin Jember. Retrieved from Skripsi Sarjana/UT Faculty of Economic \& Business New: http://repository.unej.ac.id/handle/123456789/98893

Ressya, R. (2014). Pengaruh Pembelajaran Organisasi terhadap Kinerja dengan Kompetensi sebagai Mediasi pada PT Jasa Marga (Persero) Tbk. Cabang Purbaleunyi. Digital LibraryPerpustakaan Pusat Unikom. Retrieved from https:/ / elib.unikom.ac.id.

Sanjaya, R. (2018). Pengaruh Motivasi Kerja terhadap Kinerja Pegawai dalam Perspektif Ekonomi Islam (Studi di Dinas Sosial Tenaga Kerja dan Transmigrasi Kabupaten Pesisir Barat. Retrieved from radeninten: http://repository.radenintan.ac.id/id/eprint/3563.

Sarafino, E. P., \& Smith, T. W. (2014). Health psychology: Biopsychosocial Interactions. Hoboken, NJ: John Wiley \& Sons, Inc.

Senge, P. M. (2006). The fifth discipline. The art and practice of the learning organization. Rev. ed. New York, London: Currency Doubleday.

Sitepu, A. J. (2018). Pengaruh Dukungan Sosial, Stres Kerja, dan Kepuasan Kerja terhadap Kinerja Anggota pada Satuan Reserse Narkoba di Kepolisian Resor Banjarbaru. KINDAI, Vol.14 (3), 201-209. https://ejournal.stiepancasetia.ac.id 
Sonia, Z. (2021). Pengaruh Dukungan Sosial terhadap Kinerja Karyawan di Masa Pandemi Covid-19 dengan Komitmen Afektif sebagai Variabel Mediasi (Studi Kasus pada Perawat RSU Islam Klaten.

http://repository.unwidha.ac.id/2333/1/Zulfa\%20Fix.pdf

Sugiyono. (2019). Statistika untuk Penelitian. Bandung: CV Alfabeta.

Suryono, A. (2011). Manajemen Sumber Daya Manusia: Etika dan Standar Profesional Sektor Publik. Malang: UP Press.

Susita, D., \& Setyawati, W.P. (2020). Pengaruh Motivasi Kerja dan Komitmen Organisasi pada Kinerja Pegawai PT X. Jurnal Riset Manajemen Saint Indonesia, Vol.11(No.1). Doi:https:// doi.org/10.21009/JRMSI.011.1.010

Srimulatsih, M. (2021). Pengaruh Pembelajaran Organisasi terhadap Kinerja Karyawan pada PT Huahean Pekanbaru. Eko dan Bisnis (Riau Economic and Business Review, Vol 12 Nomor 2, 167-174. Doi: https:// doi.org/10.36975/jeb.v12i2.326

Tika, P. (2014). Budaya Organisasi \& Peningkatan Kinerja Pegawai. Jakarta: Bumi Aksara.

Tjakraatmadja, Hidajat, Lantu, \& Crestofel. (2014). Knowledge; Management dalam Konteks Organisasi Pembelajar. Bandung: SBM ITB.

Uniati, M.I. (2014). Learning Organization; Komitmen pada Organisasi, Kepuasan Kerja, Efektivitas Penerapan Sistem Iso \& Dampaknya terhadap Kinerja Organisasi (Studi Kasus Staf Administrasi UK Petra Surabaya). Jurnal Manajemen Pemasaran, Vol.8(No.1). ISSN 1977-235X. http://dx.doi.org/10.9744/pemasaran.6.1.1-7.

Uno, H.B. (2016). Teori Motivasi \& Pengukurannya Analisis di Bidang Pendidikan. Jakarta: PT Bumi Aksara.

Wirawan. (2013). Kepemimpinan; Teori Psikologi, Perilaku Organisasi, Aplikasi dan Penelitian. Jakarta: PT. Raja Grafindo Persada.

Wirotama, S. (2017). Mengembangkan Learning Organization dalam Perusahaan Melalui HRD. Retrieved from samahitawirotama.com: https://samahitawirotama.com. 